\title{
Obama versus McCain on science and education
}

\author{
A comparison of the candidates' positions on issues related to science and education points to some clear differences.
}

(1) $\mathrm{n}$ the upcoming US election, there are a number of extremely important issues to consider - the economy, the environment and energy, and the war in Iraq, to name just a few. What plans do the candidates have to improve the economy and meet the major challenges, such as climate change, energy, education and health care-all of which depend on a first-rate education system and a commitment to basic science research?

These issues can be complicated, and so a coalition of scientists, engineers and concerned citizens known as ScienceDebate2008 had wanted the candidates to participate in a debate on science and technology policy issues. Although they did not succeed, they did get both to agree to answer some questions. Of the 3,400 member-submitted questions, the group managed to condense the list of questions down to 14, which they asked the candidates to answer in writing.

Obama was first to answer these questions at the end of August, and more recently McCain also weighed in. All of the questions and the full answers can be found at http://www.sciencedebate2008.com. Here I will highlight just a few questions and some excerpts from the candidates' answers. Where the answers were not as specific as I would have liked, I will quote from previous statements that they have made and also from their campaign websites or from their party's platform.

Overall, Obama's answers are more specific and consistent with previous statements he has made and with his party's platform. McCain, on the other hand, seems to want to be all things to all people (including the candidate of change). For example, while he states that he supports federal funding for embryonic stem cell research he goes on to talk about drawing clear moral lines. Exactly what this means is anyone's guess and I suspect it is meant to be purposefully ambiguous so that one can read whatever one wants into such a statement. Moreover, his party platform opposes federal funding for embryonic stem cell research and his vice presidential running mate, Sarah Palin, wants to ban all stem cell research. And there are other examples. Palin supports the teaching of creationism in schools, and doesn't believe that global warming is man-made. (I will leave aside the fact that she believes abortion should be illegal even in cases of rape or incest, or to save the life of the mother, because this is such a hot-button issue, even though it is arguably a matter of both science and education.) Given these different positions which would prevail in a McCain administration? The answer seems at best unclear.

Education. A comparison of 15-year-olds in 30 wealthy nations found that average science scores among U.S. students ranked 17th, while average U.S. math scores ranked 24th. What role do you think the federal government should play in preparing $K-12$ students for the science and technology driven 21 st century?

Obama has proposed an $\$ 18$ billion increase in spending for all federal education programs, some of whichincludeincreasing the number of graduates and undergraduates pursuing degrees in science, technology, engineering and mathematics fields and establishing a Teaching Service Scholarship program for recruiting math, science and technology degree graduates.

McCain's education policy emphasizes improvements through competition among schools (and programs such as school vouchers), accountability and standardized tests.

Obama: "What you see consistently are children at a very early age are starting school already behind. ... And that's why I've said that I'm going to put billions of dollars into early childhood education. ... Every dollar that we spend in early childhood education, we get $\$ 10$ back in reduced dropout rates, improved reading scores."(Democratic debate, 15 January 2008)

McCain: "There is no shortage of federal programs targeted at early child care and preschool. ... There is much to be achieved by leveraging and better coordinating these programs to increase availability of high-quality programs. ... Federal dollars can do far more to broaden access to high quality programs." (Campaign website)

Obama: "But we should only do [merit pay] if the teachers themselves have some buy-in in terms of how they're measured. They can't be judged simply on standardized tests that don't take into account whether children are prepared before they get to school or not." (Democratic debate, 19 August 2007)

McCain: "The first 35 percent of Title II funding would be directed to the school level. ... I will devote 60 percent of Title II funding for incentive bonuses for high performing teachers to locate in the most challenging educational settings, for teachers to teach subjects like math and science, and for teachers who demonstrate student improvement." (ScienceDebate2008.com)

A question that was not one of the 14, but which is relevant to the education question, is whether the candidates believe in evolution and whether they think that intelligent design should be taught alongside it.

Obama: "I do believe in evolution. I don't think that is incompatible with Christian faith, just as I don't think science generally is incompatible with Christian faith. There are those who suggest that if you have a scientific bent of mind, then somehow you should reject religion. And I fundamentally disagree with that. In fact, the more I learn about the world, the more I know about science, the more I'm amazed about the mystery of this planet and this 
universe. And it strengthens my faith as opposed to weakens it." (Democratic forum, 13 April 2008)

McCain: “I believe in evolution.” (Republican debate, 3 May 2007)

"But I think that every American should be exposed to all theories. ... There's no doubt in my mind that the hand of God was in what we are today. And I do believe that we are unique, and I believe that God loves us. But I also believe that all of our children in school can be taught different views on different issues. I leave the curricula up to the school boards." (Republican debate, 5 June 2007)

Stem cells. Stem cell research advocates say it may successfully lead to treatments for many chronic diseases and injuries, saving lives, but opponents argue that using embryos as a source for stem cells destroys human life. What is your position on government regulation and funding of stem cell research?

Obama: "I strongly support expanding research on stem cells. As president, I will lift the current administration's ban on federal funding of research on embryonic stem cell lines created after August 9, 2001 through executive order, and I will ensure that all research on stem cells is conducted ethically and with rigorous oversight." (ScienceDebate2008.com)

McCain: "While I support federal funding for embryonic stem cell research, I believe clear lines should be drawn that reflect a refusal to sacrifice moral values and ethical principles for the sake of scientific progress. Moreover, I believe that recent scientific breakthroughs raise the hope that one day this debate will be rendered academic. I also support funding for other research programs, including amniotic fluid and adult stem cell research which hold much scientific promise and do not involve the use of embryos. I oppose the intentional creation of human embryos for research purposes and I voted to ban the practice of "fetal farming," making it a federal crime for researchers to use cells or fetal tissue from an embryo created for research purposes." (ScienceDebate2008.com)

As I said before the Republican party platform opposes federal funding for embryonic stem cell research. (http://www.gopplatform2008.com)

Scientific integrity. Many government scientists report political interference in their job. Is it acceptable for elected officials to hold back or alter scientific reports if they conflict with their own views, and how will you balance scientific information with politics and personal beliefs in your decision-making?

Obama: "I will restore the basic principle that government decisions should be based on the best-available, scientifically valid evidence and not on the ideological predispositions of agency officials or political appointees. I will:

- Appoint individuals with strong science and technology backgrounds...to...senior management positions where decisions must incorporate science and technology advice.

- Establish the nation's first Chief Technology Office....

- Strengthen the role of the President's Council of Advisors on Science and Technology (PCAST) by appointing experts who are charged to provide independent advice on critical issues of science and technology.
- Restore the science integrity of government and restore transparency of decision making by issuing an Executive Order establishing clear guidelines for the review and release of government publications...." (ScienceDebate2008.com)

McCain: "I support having a science and technology advisor within the White House staff and restoring the credibility and role of Office of Science \& Technology Policy (OSTP) as an office within the White House structure. I will work to fill early in my administration both the position of Science Adviser and at least four assistant directors within OSTP. I am committed to asking the most qualified scientists and engineers to join not only my OSTP, but all of the key technical positions in my administration." (ScienceDebate2008.com)

Research. For many years, Congress has recognized the importance of science and engineering research to realizing our national goals. Given that the next Congress will likely face spending constraints, what priority would you give to investment in basic research in upcoming budgets?

Obama: "As president, I will increase funding for basic research in physical and life sciences, mathematics, and engineering at a rate that would double basic research budgets over the next decade. ... Sustained and predictable increases in research funding will allow the United States to accomplish a great deal. First, we can expand the frontiers of human knowledge. Second, we can provide greater support for high-risk, highreturn research and for young scientists at the beginning of their careers. Third, we can harness science and technology to address the "grand challenges" of the 21st century: energy, health, food and water, national security, information technology, and manufacturing capacity." (ScienceDebate2008.com)

\begin{abstract}
McCain: "I am committed to reinvigorating America's commitment to basic research, and will ensure my administration funds research activities accordingly. I have supported increased funding at DOE, NSF, and NIH for years and will continue to do so. I will continue my commitment to ensure that the funding is properly managed and that the nation's research needs are adequately addressed." (ScienceDebate2008.com)
\end{abstract}

In sum, Obama proposes $\$ 18$ billion a year in new federal spending on early-childhood classes, teacher recruitment, performance pay and other initiatives. McCain believes that the federal government should have a limited role in public education and that competition among schools should prevail. Both believe in evolution, and Obama states clearly that intelligent design should not be taught alongside it, whereas McCain thinks school districts should decide whether to teach other ideas. Both are committed to basic research, although Obama has been more specific — saying that he will double the basic research budget over the next 10 years.

One could argue that both candidates could have been more specific in their answers. But while Obama has been consistent in his positions, there is a disconnect between the answers McCain has provided on ScienceDebate08, the positions of the Republican party platform and those of Palin. This begs the question of what the policies on stem cell research, science education (vis-à-vis the teaching of evolution) and climate change would be in a McCain presidency. I for one want to know (not have to guess) what the policies of the person I am voting for would be if they were to be elected. Of course, there's no guarantee that they will do what they say, but it's a good place to start. 